\title{
Maybe it's us: Imagining Organisational Learning Design
}

\author{
Sarah Thorneycroft \\ University of New England
}

\begin{abstract}
Higher education is in crisis mode, and as organisations we need to find new ways to exist. The traditional entities tasked with change in the sector have had limited impact, however, and it may be time to explore new catalysts for organisational change. This short narrative paper describes one such potential catalyst, the concept of organisational learning design - a new practice domain that harnesses the capabilities and affordances of learning design and evolves them beyond technology into organisational learning and organisational culture practices to create a high-leverage change agent.
\end{abstract}

Keywords: Learning design, organisational learning, organisational culture, change agency

\section{Higher Education in 2020: Portrait of a sector on fire}

Higher education, and the work we do within it, has faced an onslaught of crises over the last decade. Rhetoric and circumstances permeate all aspects of our existence - from our role and relevance in society to financial decimation by a global pandemic; from disruptive innovation from alternative providers to calls for work-ready graduates; from rampant casualisation to research relevance; from the corporatisation of education to the continual slashing of government funding. Our existence is precarious and our future unknown.

A common theme to all of these crisis narratives is an inability for universities to adapt and respond to change - an inability to learn as an organisation. One needs only to look to the organisational learning literature to see that universities are often portrayed as counter-examples (Gibbons et al., 1994; Lipshitz, Friedman \& Popper, 2006) organisations that certainly, and ironically, do not learn in any kind of effective sense. The flip side of this same coin is organisational culture (Schein, 2004; Trice \& Beyer, 1993) - the human foundation of our organisations that facilitates our learning and growth, or more likely, does not. Universities are portrayed equally unfavourably in the organisational culture literature (Fitzpatrick, 2019; Smyth, Smyth \& Christie, 2017).

So perhaps rather than a crisis of circumstance, universities are facing a crisis of organisational learning and organisational culture. Do we need to shift our focus of change internally to ourselves, examine the ways we exist as organisations and create new ways of doing and being? Do we need to look beyond what's already been done into new domains? And once we ask these questions, another question emerges - who will do this work? Who can we look towards to catalyse this change?

\section{Who's going to fix it?}

The question of who can be asked to address organisational learning and culture is not a new one - there are several entities who are traditionally seen as responsible for this work. However, each of these have challenges that mean their impact is limited. Some examples of these from across the literature are given below to illustrate these entities and limitations.

Frequently, organisational learning and culture is conceptualised as a top-down responsibility of formal executive leadership (Bass \& Avolio, 1993; Dodgson \& Gann, 2019). There is a lack of confidence and evidence that the leadership of higher education institutions is up to the task, however (Connell, 2019; Devinny \& Dowling, 2020). There are also the contrary views of organisations and leadership that suggest all employees have agency and responsibility for organisational learning and culture rather than responsibility falling to leadership (Goldstein, Hazy and Lichtenstein, 2010; Schein 1993). University leadership, then, is unlikely to be the solution.

HR and Organisational Development departments are another area tasked with leading initiatives in developing organisational learning and culture capability. However, their programs often follow a corporate training model of transmissive learning (Antonacopolou, 2006), rather than employing effective learning models and pedagogical practices. HR programs can further be limited by a lack of systemisation and reaching only a few targeted staff (Zheltoukova, 2014). Consequently, it is unlikely that HR departments will be able to catalyse change. 
External consultancy is an often-used intervention, but consultants often fail to have sustained impact due to being divorced from the institutional context - complex systems can only effectively be changed by agents within the system, native to the context (Yunkaporta, 2019). While there is no single model of consultancy, extended engagement is expensive and gaining in-depth contextual knowledge would generally not be cost- effective, especially in times of financial crisis. Therefore, it is unlikely that we can rely on consultancy to change our organisations.

Academic development units offer learning programs grounded in effective pedagogy to develop staff capabilities. However, the content of these programs is almost exclusively around the scholarship of teaching and learning, educational technologies and other teaching-focused domains (Bath \& Smith, 2004; Debowski, 2014). They are not focused on developing staff capabilities in the domains of organisational learning and culture. Academic development is unlikely to be the solution.

The subject matter experts in this domain, academics in the organisational behaviour disciplines, have theoretical expertise in organisational learning and culture, but in general they have very little agency in the operation of the organisation as they are compelled to function as an academic discipline, with KPIs in research and teaching. Kogan and Tiechler (2007) also somewhat crudely refer to academic staff as 'amateurs' in shaping the university. So, while they provide us with the theoretical understanding, it's unlikely organisational behaviour academics will be able to effect change.

Who, then, might be able to catalyse the change we need? Cooksey (2011) talks about the emergence of boundaryspanning roles that move across and between traditionally defined domains and act as knowledge brokers in innovation and change. There is one group of people in universities whose agency in organisational learning and culture has been largely unexplored to date, but who might have significant ability to fill this boundary-spanning niche - learning designers.

\section{Maybe it's us?}

Learning design (and its related roles) as a profession has traditionally focused on supporting academic staff in the design and delivery of teaching, often with a strong focus on the technological domain of online learning. However, learning design has a rich and complex set of affordances and capabilities that could be applied in new domains to create a new type of work: organisational learning design. The following paragraphs identify some of those affordances and capabilities as a means of illustrating our potential to step into a new boundary-spanning niche. The thread drawn through these affordances and capabilities then leads to the definition of a term to name this niche.

Our pedagogical expertise and ability to design circumstances that effectively allow learning to happen easily apply themselves to how people in an organisation learn. We also, tacitly or explicitly, have expertise in the frameworks that conceptualise learning in the organisational learning literature. For instance, double and triple loop learning (Argyris \& Schön, 1978; Flood \& Romm, 1996; Peschl, 2007) are core to the work of learning design as we lead those around us to understand the how and why of learning and teaching. We also have expertise in design processes and design thinking, which can be easily applied to domains outside of student learning - for instance, intentionally designing artefacts of organisational culture (Ozenc \& Hagan, 2017).

We also have many tacit skills in the way we conceptualise and navigate our human work within the university landscape - we are skilled systems thinkers (Pesina, 2019) and position our work and the work of learning within a complexity frame of reference (Byrne, 2014). Systems thinking and complexity theory are instrumental to organisational learning (Senge, 1990) and position us well to move into this new domain. The ways we engage in our work - constant partnership, leadership or support relationship with stakeholders across the institution - lends us significant affordances around catalysing change. This has been variously described as being stealth change agents (Ramos-Torrescano, 2017), agents of social change (Campbell, Schwier \& Kenny, 2005) and partners in arms (Debowski, 2014). Our existence in the Third Space (Whitchurch, 2008) also gives us 'occupational freedoms' that aren't afforded to academic or administrative staff (Bath \& Smith, 2004) and expertise in shaping the university (Kogan \& Tiechler, 2007).

Further, to draw in a very recent perspective, a study has shown that the COVID-19 pandemic and the sudden shift to fully online delivery it catalysed has enabled more meaningful collaboration and partnership with academic staff and greater recognition of learning design expertise and capabilities (Bellaby \& Sankey, 2020). The same study also describes moving beyond learning design work to the provision of pastoral care to academic staff, which suggests a lean into cultural work. It may be thus be the case that this particular point in time and space is a prime opportunity to capitalise on our increased agency and recognition. 
Harnessing these capabilities and affordances of learning design and evolving them into the new domains of organisational learning and organisational culture - emerging the new concept of organisational learning design may be what Senge (1990) refers to as a high-leverage change point. Organisational learning design - whether a set of practices, a body of work or a formal role - could be the human, agile, context-native agent needed for meaningful change. Figure 1 illustrates this emergence of organisational learning design at the nexus of capabilities and affordances:

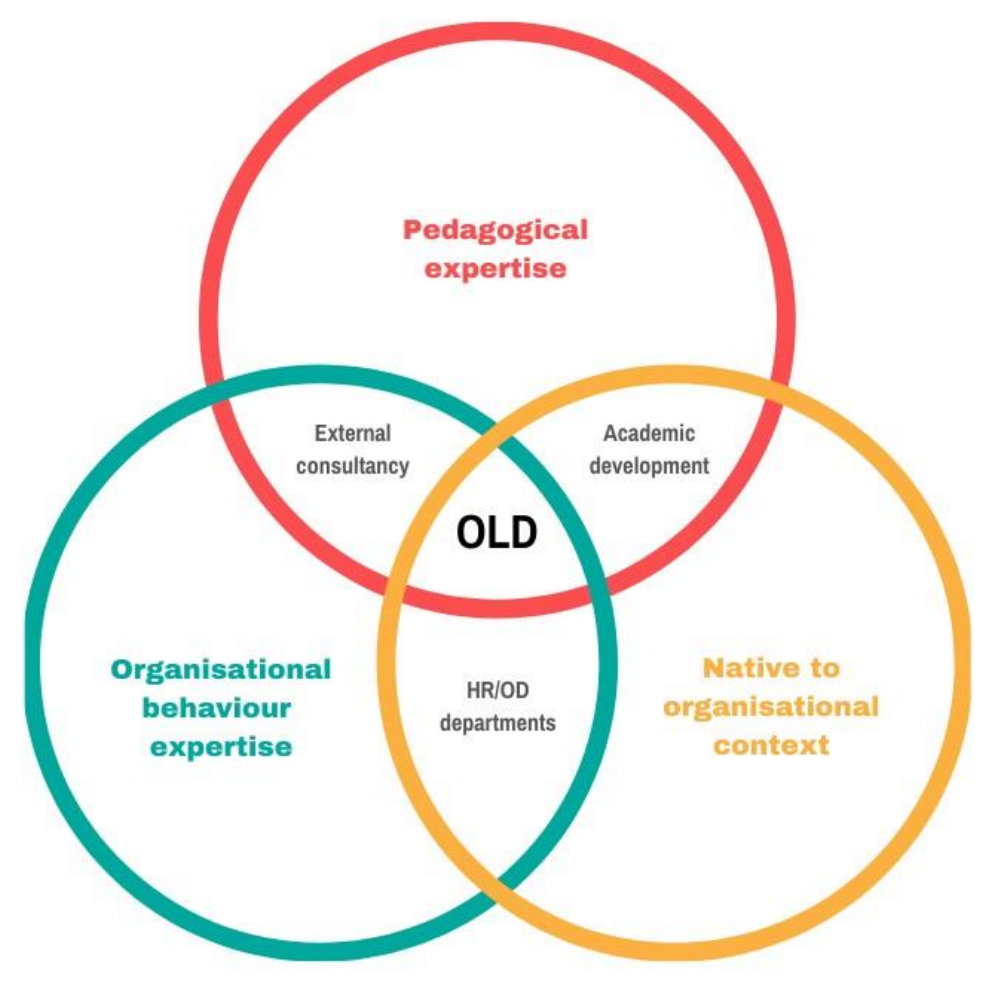

Figure 1: The emergence of organisational learning design (OLD)

\section{How would we do it?}

While an in-depth exploration of what organisational learning design might look like in practice is beyond the scope of this concise paper, this is a key area for future exploration. The nexus between the individual learning literature and the organisational learning and culture literatures emerges many potential ways that our practice lens can be refocused. Some of these are captured below as avenues for future exploration:

- Leading design thinking processes to create new rituals (Ozenc \& Hagan, 2017) and new aspects of other cultural domains such as languages (Kegan \& Lahey, 2002) and artefacts (Higgins \& Mcallaster, 2004)

- Foregrounding the organisational learning loops (Argyris \& Schön, 1978; Flood \& Romm, 1996;

- Peschl, 2007) in our work practices

- Designing work environments that promote psychological safety (Edmondson, 1999)

- Applying the principles of constructive alignment (Biggs, 1996) in work practices to align performance indicators and project goals (learning outcomes) with work practices (learning activities) and deliverables (assessment)

- Embodying our practice as designers (Adam, 2020) across our institutions, planting seeds of change in

- 'cultural islands' (Lipshitz, Friedman \& Popper, 2006)

- Designing and facilitating the practice of 'learnership' (Cooksey, 2003) in our institutions 
- Leveraging our roles as generative leadership spaces to lead change (Goldstein, Hazy and Lichtenstein, 2010)

These avenues are a starting point for a conversation across the sector, a 'call to arms', as it were, for learning designers to come together and begin exploring this new niche together as a profession. Many of these avenues lend themselves to developmental or iterative practice-based methods of exploration, that can leverage the current climate to begin exploration in areas of potential immediate impact. Over time, our collective exploration as practitioners can build an answer to the question - what is the work of organisational learning design?

\section{Conclusion}

The crisis currently facing higher education could be framed as a crisis of organisational learning and culture, which opens up new directions for exploring solutions, rather than continuing to look to traditional domains of such as senior leaders, consultants and HR departments. One such direction is the exploration of a new role and new type of work for universities - organisational learning design. Drawn from promising connections across various bodies of literature, this role represents an evolution of the capabilities and affordances of the learning design profession beyond technology into the domains of organisational culture and learning.

In times of crisis, it's necessary to think outside of what has already been done, into new domains of 'maybe' and 'what if'. In this vein, maybe organisational learning design could be the high-leverage catalyst we need to see real change in universities. Maybe, after all the narratives of other 'more qualified' people carrying organisational learning and culture, it's not them - maybe, after all, it's us.

\section{References}

Adam, T. (2020). Open educational practices of MOOC designers: embodiment and epistemic location. Distance Education, 41(2), 171-185. https://doi.org/10.1080/01587919.2020.1757405

Antonacopoulou, E. P. (2006). The relationship between individual and organizational learning: New evidence from managerial learning practices. Management Learning, 37(4), 455-473.

Argyris, C. \& Schön, D. (1978). Organizational learning. Reading, Mass: Addison-Wesley.

Bass, B., \& Avolio, B. (1993). Transformational Leadership and Organizational Culture. Public Administration Quarterly, 17(1), 112-121. Retrieved from http://www.jstor.org/stable/40862298

Bath, D. \& Smith, C. (2004) Academic developers: an academic tribe claiming their territory in higher education. International Journal for Academic Development, 9(1), 9-27, DOI: $10.1080 / 1360144042000296035$

Bellaby, A. \& Sankey, M. (2020). Educational Designers: A sure hope and anchor amid a global pandemic. Retrieved from https://blog.ascilite.org/educational-designers-a-sure-hope-and-anchor-amid-a-globalpandemic/

Biggs, J. (1996). Enhancing teaching through constructive alignment. Higher Education, 32(3), 347-364.

Byrne, D. (2014). Thoughts on a pedagogy of complexity. Complicity: An International Journal of Complexity and Education, 11(2).

Campbell, K., Schwier, R. A. \& Kenny, R. F. (2005). Agency of the instructional designer: Moral coherence and transformative social practice. Australasian Journal of Educational Technology, 21(2), 242-262. Retrieved from http://www.ascilite.org.au/ajet/ajet21/campbell.html

Connell, R. (2019). The good university: What universities actually do and why it's time for radical change. Bloomsbury, UK: Zed Books.

Cooksey, R.W. (2003). “Learnership” in complex organisational textures. Leadership \& Organization Development Journal, 24(4), 204-214.

Cooksey, R.W. (2011). Yours, mine or ours: What counts as innovation? Journal of Agricultural Education and Extension, 17(3), 283-295.

Devinney, T. \& Dowling, G. 2020. Is this the crisis higher education needs to have? Times Higher Education. Retrieved from https://www.timeshighereducation.com/features/crisis-higher-education-needs$\underline{\text { have }}$

Dodgson, M., \& Gann, D. 2019. This is why universities need strong strategic leadership. World Economic Forum. Retrieved from https://www.weforum.org/agenda/2019/11/universities-need-excellent-strategicleadership-here-s-what-it-looks-like/ 
Edmondson, A. (1999). Psychological safety and learning behavior in work teams. Administrative Science Quarterly, 44(2), 350-383.

Fitzpatrick, K. (2019). Generous thinking: A radical approach to saving the university. Baltimore: JHU Press.

Flood, R. L., \& Romm, N. R. A. (1996). Contours of diversity management and triple loop learning. Kybernetes, 25(7), 154-163.

Gibbons et al. (1994). The New Production of Knowledge: The Dynamics of Science and Research in Contemporary Societies. London: Sage.

Goldstein, J., Hazy, J.K. \& Lichtenstein, B.B. (2010). Introduction: A new science of leadership. In Complexity and the nexus of leadership: Leveraging nonlinear science to create ecologies of innovation (1-17). New York: Palgrave Macmillan,

Higgins, J. \& Mcallaster, C. (2004) If you want strategic change, don't forget to change your cultural artifacts. Journal of Change Management, 4(1), 63-73, DOI: 10.1080/1469701032000154926

Kegan, R. \& Lahey, L. (2002). How the Way We Talk Can Change the Way We Work: Seven Languages for Transformation. San Francisco: Jossey-Bass.

Kogan, M. \& Teichler, U. (2007). Key Challenges to the Academic Profession. Retrieved from http://lstiiep.iiep-unesco.org/cgi-bin/wwwi32.exe/[in=epidoc1.in]/?t2000=024165/(100)

Lipshitz, R., Friedman, V., \& Popper, M. (2006). Demystifying organizational learning. Thousand Oaks, California: Sage.

Ozenc, F. \& Hagan, M. (2017). Ritual Design: Crafting Team Rituals for Meaningful Organizational Change. Advances in Intelligent Systems and Computing, Proceedings of the Applied Human Factors and Ergonomics International Conference, 2017. Springer Press. Retrieved from https://ssrn.com/abstract=2994394

Peschl, Markus F. (2007) Triple-loop learning as foundation for profound change, individual cultivation, and radical innovation. Construction processes beyond scientific and rational knowledge. Constructivist Foundations, 2(2-3).

Ramos-Torrescano, E. (2017). Instructional Designers as (Secret) Change Agents. Retrieved from https://www.iddblog.org/?p=3130

Schein, E. H. (1993). On dialogue, culture, and organizational learning. Organizational Dynamics, 22(2). Retrieved from https://link.galegroup.com/apps/doc/A14606098/AONE?u=googlescholar\&sid=AONE\&xid=7b62f181

Senge, P. M. (2006). The fifth discipline: The art and practice of the learning organization. New York: Doubleday.

Smyth, J., Smyth, \& Christie. (2017). Toxic University. London: Palgrave Macmillan.

Trice, H. M., \& Beyer, J. M. (1993). The cultures of work organizations. Englewood Cliffs, NJ: Prentice-Hall.

Whitchurch, C. (2008). Shifting identities and blurring boundaries: the emergence of Third Space professionals in UK higher education. Higher Education Quarterly, 62(4), 377-396. Retrieved from https://onlinelibrary.wiley.com/doi/full/10.1111/j.1468-2273.2008.00387.x

Yunkaporta, T. (2019). Sand talk: How indigenous thinking can save the World. Melbourne, Text Publishing.

Thorneycroft, S. (2020). Maybe It's Us: Imagining Organisational Learning Design. In S. Gregory, S. Warburton, \& M. Parkes (Eds.), ASCILITE's First Virtual Conference. Proceedings ASCILITE 2020 in Armidale (pp. 90-94). https://doi.org/10.14742/ascilite2020.0123

Note: All published papers are refereed, having undergone a double-blind peer-review process.

The author(s) assign a Creative Commons by attribution licence enabling others to distribute, remix, tweak, and build upon their work, even commercially, as long as credit is given to the author(s) for the original creation.

(C) Thorneycroft, S. 2020 